\title{
Correction to: Restless Cities on the Edge
}

\section{Correction to:}

\section{A. L. Farro, S. Maddanu, Restless Cities on the Edge, Migration, Diasporas and Citizenship, https://doi.org/10.1007/978-3-030-91323-6}

The original version of this book was published with incorrect affiliation for the 2 nd author Dr. Simone Maddanu. It has now been changed from "University of Tampa" to "University of South Florida" in this revised version.

The updated version of this book can be found at https://doi.org/10.1007/978-3-030-91323-6

(C) The Author(s), under exclusive license to Springer Nature Switzerland AG 2022

A. L. Farro, S. Maddanu, Restless Cities on the Edge, Migration, Diasporas and Citizenship, https://doi.org/10.1007/978-3-030-91323-6_8 